\title{
A Modeling Study of Perched Water Phenomena in the Vadose Zone
}

\author{
Y. S. Wu, A. C. Ritcey and G. S. Bodvarsson \\ Earth Sciences Division \\ Lawrence Berkeley National Laboratory
}

The presence of perched water bodies in the vicinity of the potential repository at Yucca Mountain has many implications, and however, it may provide insight into moisture movement, flow pathways, or surface infiltration history of the mountain. The first implication is that percolation flux does not travel vertically through the unsaturated zone to the water table, but has been trapped, blocked or diverted laterally. As a result, nonuniform recharge rates are expected at the water table. Another concern is that perched zones may divert water around low-permeability zeolitic lenses underlying the potential repository horizon. By-passing of these units, which are thought to have substantial capacity to retard radionuclide transport, could have important implications for the capability of the geologic system to mitigate radionuclide releases to the environment.

We have conducted a series of 3-D modeling simulations to investigate the perched water occurrences at the Yucca Mountain site, using a numerical code and available perched water data from six boreholes. A spatially varying surface infiltration map (Flint et al., 1996) is used to describe areally distributed net infiltration at the model land surface. Perched water data observed in the field were used to calibrate the model in terms of matrix and fracture permeabilities, capillary functions, and relative permeabilities of gas within the perched zones. Calibrated parameter values were within the range of field and 
laboratory measurements. The steady-state simulation results are in agreement with the observed perched water data in terms of water saturation and perched water locations. Furthermore, the results of a transient numerical pumping test conducted, using a 3-D submodel, matched water level data observed during field pumping tests.

Perched-water has been intersected in a number of boreholes (UZ-14, NRG-7a, SD-9, and G-2), at Yucca Mountain (Striffler et al.; 1996). Perched water was also found at borehole SD-7 (Czamecki; 1995), (Personal Communication, Soeder; USGS, 1995), and . wet core was recovered from borehole SD-12 (Patterson; 1996). The observed perched data are listed in Table 1.

\begin{tabular}{|c|c|c|c|c|c|c|}
\hline \multicolumn{7}{|c|}{ 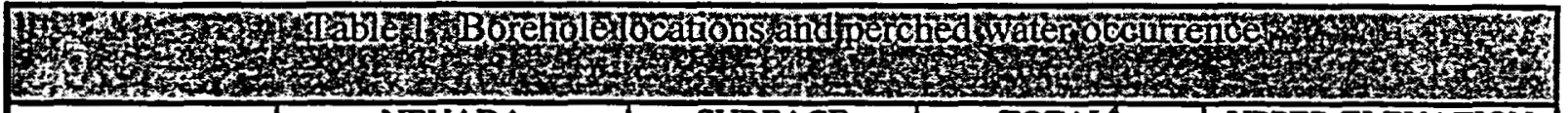 } \\
\hline & \multicolumn{2}{|c|}{$\begin{array}{l}\text { NEVADA } \\
\text { COORDINATES' }\end{array}$} & $\begin{array}{c}\text { SURFACE } \\
\text { ELEVATION }^{1}\end{array}$ & $\begin{array}{l}\text { TOTAL } \\
\text { DEPTH }\end{array}$ & \multicolumn{2}{|c|}{$\begin{array}{l}\text { UPPER ELEVATION } \\
\text { OF PERCHED } \\
\text { ZONE }\end{array}$} \\
\hline BOREHOLES & $\begin{array}{l}\text { North } \\
\text { (m) }\end{array}$ & $\begin{array}{l}\text { East } \\
\text { (m) }\end{array}$ & (masl) & (m) & $\begin{array}{c}\text { Elevation } \\
\text { (masl) }\end{array}$ & $\begin{array}{l}\text { Depth } \\
\text { (m) }\end{array}$ \\
\hline UZ-14 & 235095 & 170731 & 1349 & 673 & 966 & 383 \\
\hline NRG-7 $a^{2}$ & 234355 & 171598 & 1282 & 461 & 821 & $458-461$ \\
\hline SD-73 & 231328 & 171066 & $1359^{5}$ & 632 & 880 & $480^{5}$ \\
\hline SD-9' & 234086 & 171242 & 1302 & 678 & $889^{4}$ & $413^{4}$ \\
\hline SD-12" & 232244 & 171178 & $1324^{\circ}$ & $660^{\circ}$ & $926^{\circ}$ & $398^{6}$ \\
\hline $\mathbf{G}-2^{10}$ & 237386 & 170842 & 1554 & 1891 & $1020^{\prime}$ & $534^{\prime}$ \\
\hline
\end{tabular}

'EG\&G Energy Measurements (1994). 
${ }^{2}$ Geslin et al. (1994).

${ }^{3}$ Rautman and Engstrom (1996a).

4Striffler et al. (1996).

${ }^{3}$ Czarnecki (1995) and Soeder (1995).

6Patterson (1996).

'Craig, R. W. (1995).

'Engtrom, D. A. and Rautman, R. A. (1996) and Moyer et al. (1995a).

'Rautman and Engstrom (1996).

${ }^{10}$ Maldonado and Koether (1983).

Perched water may occur where percolation flux exceeds the capacity of the geologic media to transmit flux in unsaturated zones. The conceptual model of water movement in the vicinity of investigating the perched water zones indicates that: 1) no large-scale connected fractures intersect the underlying low-permeability units, and 2) both vertical and horizontal permeabilities within the perched water zone must be small when compared with measurements outside these zones.

This modeling study indicates that the key factors necessary to create a perched-water zone using a numerical model are: (1) a water perching geologic structure with low permeability zones or a capillary barrier underlain and surrounding, (2) weak capillary forces under high saturation condition within and near perched-water zones, and (3) sufficient water infiltration rates. 